\title{
Tissue damage and haematophagia due to praniza larvae (Isopoda: Gnathiidae) in some aquarium seawater teleosts
}

\author{
F. Marino ${ }^{1, *}$, S. Giannetto ${ }^{1}$, M. L. Paradiso ${ }^{1}$, T. Bottari ${ }^{2}$, G. De Vico ${ }^{1}$, B. Macri ${ }^{1}$ \\ ${ }^{1}$ Dept. Sanità Pubblica Veterinaria, Unit of Pathology and Unit of Parasitology, University of Messina, \\ Polo Universitario dell'Annunziata, 98168 Messina, Italy \\ ${ }^{2}$ CNR-IAMC, Section of Messina, Spianata S. Raineri 86, 98122 Messina, Italy
}

\begin{abstract}
Over a 5 yr period, severe infestations due to Gnathia vorax larvae affecting different teleosts have been registered at the Civic Aquarium of Messina, Italy. Here, the damage caused by these parasites is evaluated from a macroscopical and histopathological point of view. We also attempt to evaluate the amount of blood sucked up by a single parasite and make some observations about the haematophagia. The histopathological changes confirm mucosal electrolytic failure as the main problem, even though the mean value of blood sucked up by a single parasite, about $1.9 \mathrm{mg}$, suggests that haematophagia may play an important role in the pathogenesis of such infestation. In conclusion, it was found that the G. vorax larvae caused 2-fold damage that was responsible for the death of the fish. Little by little, the parasitic problem was successfully removed by washing the tank, using fresh water rather than costly and dangerous chemotherapeutans.
\end{abstract}

KEY WORDS: Gnathia vorax · Isopoda $\cdot$ Gnathiidae $\cdot$ Teleost $\cdot$ Haematophagia $\cdot$ Histopathology

Resale or republication not permitted without written consent of the publisher

\section{INTRODUCTION}

While Gnathiidae adults live freely on the sea bottom, at the larva stage they are fish parasites. Newly hatched larvae have a brief swimming phase (zuphea) before metamorphosing into the parasitic form (praniza) and attaching themselves to a host. These isopods are spread all over the world from southern Africa (Wagele 1988, Smit et al. 1999, 2002) to the North Pole (Stefánsson 1962, Svavarsson 1999). Even though little data about their potential danger to teleosts is available, the biology of gnathids has been widely studied (Monod 1926). The presence of a large number of larvae can cause severe damage to hosts. The parasitic effects include anaemia and electrolytic failure due to mucosal damage, and sometimes death of the affected fish. Deaths from praniza larvae infestations have been reported in caged Mediterranean white bream and mullet (Paperna \& Overstreet 1981), in red porgy (Patarnello et al. 1995) and wild eels
(Mugridge \& Stallybrass 1983). Moreover, some gnathid species affect elasmobranches (Paperna \& Por 1977, Honma \& Chiba 1991, Smit \& Basson 2002).

In our previous paper we described the ultrastructural surface details of praniza larva (Giannetto et al. 1999, 2003). The aim of the present study is to evaluate the histopathological changes on different seawater teleosts observed during a Gnathia vorax larvae infestation. The finding of so many praniza larvae on parasitized fish and zuphea larvae free in the water suggested the need to study the biology of these isopods, and especially their haematophagal potential.

\section{MATERIALS AND METHODS}

A total number of 36 fish, belonging to different families and species (Table 1) caged at the Civic Aquarium in Messina (Italy), were sent to Dept. Sanità Publica Veterinaria for histopathological examination. The fish 
Table 1. List of fish species examined in this study. The number of individuals, the range of total length for each fish species and for praniza larvae, and \% mortality are reported

\begin{tabular}{|c|c|c|c|c|c|}
\hline Date & Host & Sample size & $\begin{array}{l}\text { Range of fish } \\
\text { length (mm) }\end{array}$ & $\begin{array}{c}\text { Range of Gnathia } \\
\text { vorax praniza } \\
\text { length }(\mathrm{mm})\end{array}$ & $\%$ mortality \\
\hline June 2001 & Anthias anthias & 6 & $91-98$ & $2.25-3.85$ & 100 \\
\hline June 2001 & Apogon imberbis & 4 & $70-82$ & $2.65-3.8$ & 100 \\
\hline June 2001 & Bothus podas & 2 & $83-181$ & $3-4.05$ & 100 \\
\hline February 2003 & Caranx chrysos & 2 & $128-139$ & $2.25-4.25$ & 100 \\
\hline June 2001 & Chromis chromis & 3 & $55-86$ & $2.25-4.15$ & 100 \\
\hline June 2001 & Coris julis & 6 & 118-195 & $2.3-4.25$ & 100 \\
\hline June 2001 & Dentex dentex & 1 & 201 & $2.25-5.25$ & 100 \\
\hline June 2001 & Diplodus sargus & 2 & $167-267$ & $3-4.2$ & 0 \\
\hline December 1998 & Epinephelus marginatus & 1 & 798 & $2.5-5.25$ & 100 \\
\hline June 1999, 2001 & Mugil cephalus & 3 & $156-251$ & $2.5-5.25$ & 100 \\
\hline June 2001 & Thalassoma pavo & 8 & $123-156$ & $2.5-4.25$ & 100 \\
\hline
\end{tabular}

died after severe infestations of ectoparasites; a brief description of the cases included is listed below:

- In December 1998, a grouper Epinephelus marginatus held in captivity for $20 \mathrm{yr}$, was found dead, massively infested by ectoparasites. Anamnestic data revealed that previous, less severe infestations were successfully removed by washing the tank with fresh water.

- In June 1999, another infestation caused the death of a juvenile grey mullet Mugil cephalus that was kept in the same tank as the grouper. This fish had been transferred to that tank the evening before. At that time, some praniza larvae appeared on the fins of 2 Mediterranean white bream Diplodus sargus but they survived the infestation.

- Further infestations, less severe than the first, were registered about every 6 mo. In June 2001, after the washing of the tube which carries the seawater directly from the nearby harbour, several parasites appeared in some tanks. Some labrids, 8 sea peacock Thalassoma pavo and 6 Mediterranean rainbow wrasse Coris julis, 1 dentex Dentex dentex, 3 damselfish Chromis chromis, 6 blunt-headed holy-fish Anthias anthias, 4 cardinal fish Apogon imberbis, 2 grey mullet Mugil cephalus and 2 wide-eyed flounder Bothus podas died severely infested by praniza larvae.

- Finally, in February 2003, 2 blue runners Caranx crysos died after a new parasitic attack.

Tissue samples from each of the cases listed were fixed in $10 \%$ buffered Formalin for $5 \mathrm{~d}$ and then embedded in paraffin wax. After fixation, gills and skin were decalcified in $3 \%$ trichloroacetic acid solution and $5 \mathrm{~mm}$ thick sections were stained with Haematoxylin-Eosin (H\&E).

Evaluation of haematophagia. At the sampling, the tank bottom was siphoned out to collect isopods and to evaluate the water's physical-chemical parameters.
One hundred praniza larvae attached to the body of the fish, and 30 zuphea larvae detected in the tank were collected. After drying with bibula paper, they were weighed (as $W=$ weight recorded at $0.01 \mathrm{mg}$ ) with digital precision scales and measured (as $L=$ total length recorded at $0.05 \mathrm{~mm}$ ). The length and weight mean and median values for zuphea and praniza larvae were calculated.

To evaluate the allometry of growth, the weightlength relationship was elaborated by group according to the formula: $W=a^{*} L^{\mathrm{b}}$. Weight and length data was log-transformed and the linearized relationship fitted with the least square regression was used to calculate $a$ (intercept) and $b$ (allometry or regression coefficient) coefficients. A Student's $t$-test was used to compare the $b$ coefficient in relation to the 2 different groups.

The mean weight of blood sucked up by each parasite was calculated from the difference between the relationship found for praniza and zuphea larvae. The mean value of blood sucked up per unit of length was found by considering the mean value of the ratio between the weight of sucked-up blood and the length.

\section{RESULTS}

\section{Anatomo-histopathological examination}

At necropsy, several parasitic bodies, identified as praniza larvae belonging to the genus Gnathia, were observed on the body of the fish. Larvae were spread out in the oro-pharingeal cavity, on the back as well as on the dorsal, pectoral and anal fins, and on the gills. Focal areas of depigmentation, differently sized and shaped with irregular and well-defined limits, were detected where several praniza larvae were packed together (Fig. 1). Depigmentation was better observed 


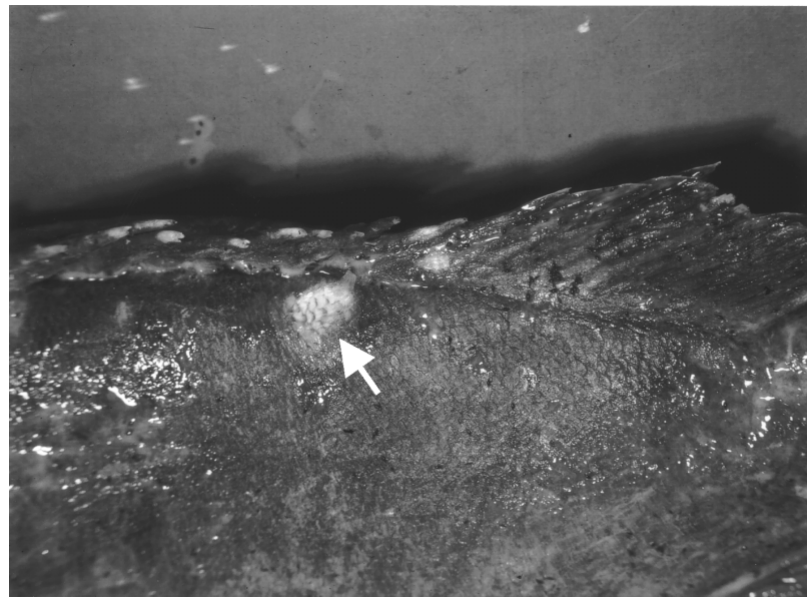

Fig. 1. Gnathia vorax on Epinephelus marginatus. Deep ulcerations, depigmentation (arrow) and fin injuries were evident where praniza larvae were concentrated

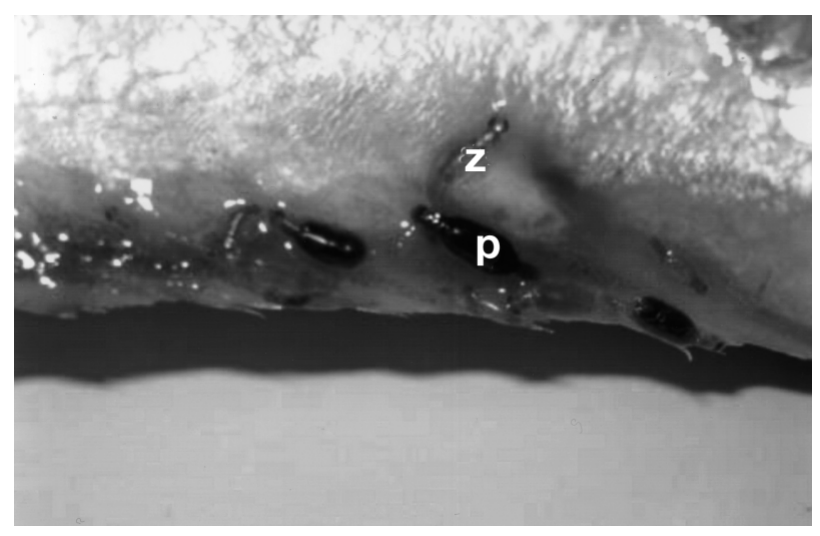

Fig. 2. Gnathia vorax pranizae on the anal fin of Caranx crysos. Praniza (p) is clearly distinguished from zuphea (z) by its dark colour due to blood meal

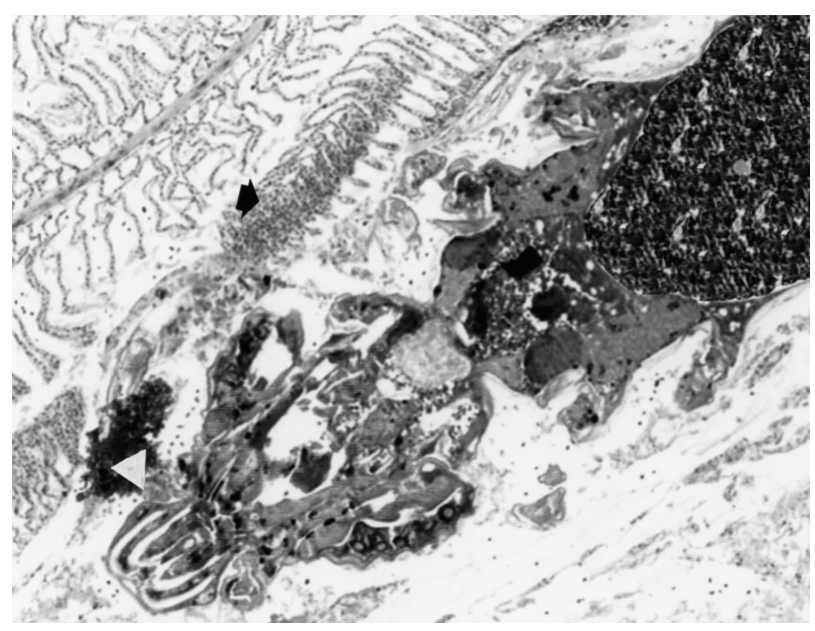

Fig. 3. Caranx crysos. Fusion of the secondary gill lamellae (arrow) was observed where isopods were attached to the host tissue by their buccal pieces (arrowhead). H\&E 10x on the grouper and on the damselfish because of their dark colour, whereas on other fish, haemorrhages were the only obvious detectable sign (Fig. 2). A pathological examination of the coelomic cavity often revealed a pale appearance of the organs, probably related to a systemic anaemia. Sometimes, during a quick, early observation, the fish showed only a few parasites on the scales of the back and the head and near the mouth, but inspection of the gills revealed that they were completely covered by praniza larvae.

Histopathology of gills showed several praniza larvae attached to the gill filaments by their oral pieces. A severe fusion of secondary lamellae was detected in the anatomical areas close to the parasites (Fig. 3). At higher magnification, a necrosis of secondary lamellae and subepithelial cellular exudation, sometimes infiltrating the deepest tissues, was observed. The infiltration mainly consisted of lymphocytes and a few eosinophils.

\section{Evaluation of haematophagia}

The weight of the larvae ranged from 0.1 to $1 \mathrm{mg}$ and from 1.6 to $5 \mathrm{mg}$ for zuphea and praniza, respectively. The mean weight for zuphea larvae was $0.4 \mathrm{mg}$ (SD = 0.25 ) and $3.2 \mathrm{mg}(\mathrm{SD}=0.79)$ for praniza larvae. The allometric coefficient value $b$ for zuphea larvae was equal to 1.55, showing a negative allometric growth; also the praniza larvae showed a negative allometric growth too $(b=0.93)$. Body length-weight relationships are shown in Fig. 4. There was a significant difference in $b$ values $(\mathrm{p}<0.01$ ) between zuphea and praniza larvae. The mean weight of sucked blood was $0.59 \mathrm{mg}(\mathrm{SD}=0.09)$ per unit length $(\mathrm{mm})$, which means

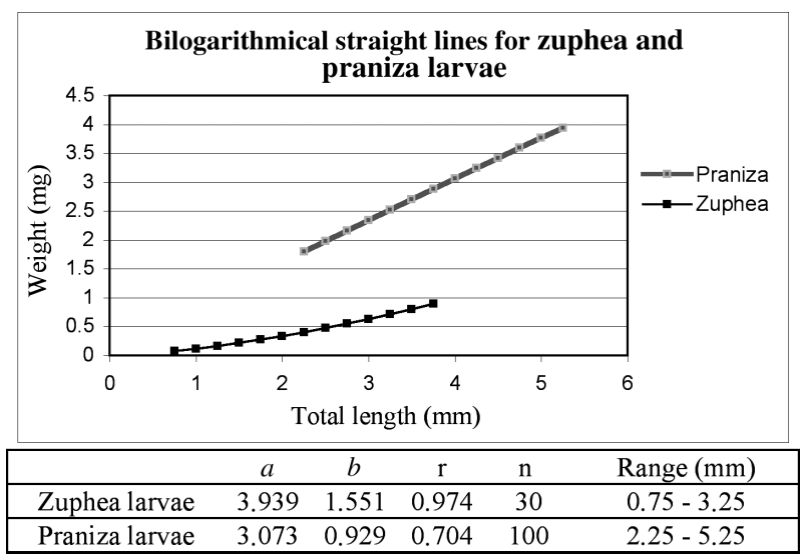

Fig. 4. Trend of the weight in relation to the length for zuphea and praniza larvae. Regression equations for zuphea and praniza larvae $(a=$ intercept; $b=$ allometric coefficient; $r=$ correlation coefficient; $\mathrm{n}=$ number of specimens; range $(\mathrm{mm})$ = length range) 
that $1.89 \mathrm{mg}(\mathrm{SD}=0.46)$ is the mean quantity of blood blocked up by a single parasite. It is interesting to underline that the smallest praniza larva $(2.25 \mathrm{~mm}$ in length) sucked up $1.32 \mathrm{mg}$ of blood, whereas the biggest praniza larva (5.25 $\mathrm{mm}$ in length) sucked up $3.07 \mathrm{mg}$.

\section{DISCUSSION}

The fish studied in this paper have been kept in tanks where both previous and further gnathid infestations were regularly observed in the months of June to July and December to January. So far, we have failed to find adult isopods, but we have found the exoskeleton of an adult gnathid male, which was helpful with regard to taxonomic identification of larvae (Giannetto et al. 2003). The topography of the aquarium and the characteristics of the tank, as well as the water pumping system that pumps seawater directly into a large tank without any mechanical or biological filtration, maintains perfect environmental conditions for the gnathids. In the hatching period, newborn larvae reach the tanks of the aquarium through the water pumping system. When larvae arrive in the tank, they probably find perfect living conditions only in those tanks where limited movement of the water, poor light and oxygenation can be found; all undoubtedly being stress-producing factors for the fish, but clearly favourable for the parasite.

With regard to the damage caused by gnathids, our results allow us to conclude that the death of the fish was the result of a double parasitic action; mechanical damage on the skin, gills and pharyngeal mucosae, as well as a haematophagal capability. In severe infestations, as 1 mullet showed in this study, mechanical damage to the gill epithelium can be widespread enough to cause the total loss of function of the entire primary lamellae with subsequent hypoxia.

As for haematophagia, data available in the literature suggests an unclear pathological significance. To evaluate the haematophagal capability of praniza larvae, we weighed the larvae, comparing the increase in weight to the different sizes. The results obtained seem to confirm what has already been reported in the literature (Monod 1926): in the first phase of their life zuphea larvae do not feed, whereas praniza larvae actively begin to look for a host where they can suck fish blood. Considering that the increase in weight at the zuphea stage is relatively significant, we conclude that the strong variations in this weight, detected in the interval of length, ranged between 2.25 and $5.25 \mathrm{~mm}$, and could be related to the amount of blood sucked up by the parasites during feeding.

The mean value of the amount of blood sucked up by a single parasite was $1.89 \mathrm{mg}(\mathrm{SD}=0.46)$. If analysed singularly, this appears to be a relatively significant result. Massive infestations by Gnathia sp., sometimes a few hundred parasites on a single fish, suggest that this result should be considered more carefully. Moreover, this value must be considered an underestimate, because it does not consider the amount of metabolised blood. It should not be forgotten that praniza larvae parasitize the host until they reach the dimension of $5 \mathrm{~mm}$, after which they fall to the bottom to moult into adults (Monod 1926). If 1 praniza larva, following our data, is able to feed on about $2 \mathrm{mg}$ of blood, and the total amount of blood in a fish is about $1 / 20$ of the live weight (Roberts 1990), we can hypothesize that a massive infestation (300 U) could cause a severe anaemic status in a small fish, i.e. $100 \mathrm{~g}$ via the sucking out of about 1/8 (600 $\mathrm{mg})$ of the total blood $(5 \mathrm{~g})$. Although it is not known how long larvae parasitize the hostMonod (1926) reports a 6 mo long period in some species-praniza larvae collected on most of the fish examined have become completely blocked up in only 1 night, suggesting that a large amount of blood can be sucked up in a very short space of time. For this reason, we consider our data to be worthy of further study, even though the blood digested was not taken into account.

Nevertheless, in the fish reported here, bearing in mind the big size of the grouper, the fast evolution of the infestation in almost all the teleosts studied and the histopathological changes observed in their tissues, we believe it necessary to underline the changes observed on the mucosae after haematophagia. Respiratory failure due to gill damage, which was surely aggravated by anaemia due to haematophagia, as well as the loss of homeostatic control due to the severe gill and skin damage, are possible causes of death.

Gnathiidae larvae present in wild fish populations cause limited or no pathology, but may become pathogenic in mariculture conditions. The present study could represent one of the few sets of data demonstrating the dangerous potential of isopods in regard to aquarium fish in an experimental model-i.e. the Civic Aquarium of Messina-reproducing the environmental conditions of the inshore aquaculture systems using fish reared in confined areas.

Acknowledgements. The authors are grateful to Dr. Enrico Navarra, Director of the Civic Aquarium of Messina, for his technical and scientific cooperation.

\section{LITERATURE CITED}

Giannetto S, Marino F, Peretti V, De Vico G (1999) Osservazioni al microscopio ottico ed elettronico a scansione su pranize di Gnathia vorax (Isopoda: Gnathiidae) in cernia 
bruna (Epinephelus marginatus). Boll Soc It Patol Ittica 11(26):58-63

Giannetto S, Marino F, Paradiso ML, Macrì D, Bottari T, De Vico G (2003) Light and scanning electron microscopy observations on Gnathia vorax (Isopoda: Gnathiidae) larvae. J Submic Cytol Pathol 35(2):161-165

Honma Y, Chiba A (1991) Pathological changes in the branchial chamber wall of stingrays, Dasyatis spp., associated with the presence of juvenile gnathids (Isopoda, Crustacea). Fish Pathol 26:9-16

Monod T (1926) Les Gnathiidae. Mémoires de la Société des Sciences naturelles du Maroc 13:1-667

Mugridge RER, Stallybrass HG (1983) A mortality of eels, Anguilla anguilla L., attributed to Gnathiidae. J Fish Dis 6: 81-82

Paperna I, Overstreet RM (1981) Parasites and diseases of mullets (Mugilidae). In: Oren OH (ed) Aquaculture of grey mullets. University Press, Cambridge, p 411-493

Paperna I, Por FD (1977) Preliminary data on the Gnathiidae (Isopoda) of the northern Red Sea, the Bitter Lakes and the eastern Mediterranean and the biology of Gnathia piscivora n. sp. Rapp p-v Reun (Monaco) 24(4):195-197

Patarnello PP, Fioravanti ML, Caggiano M, Restani R (1995)

Editorial responsibility: Wolfgang Körting,

Hannover, Germany
Infestazione da Gnathiidae (Crustacea: Isopoda) in Pagrus major. Boll Soc It Patol Ittica 17:32-36

Roberts RJ (1990) Patologia dei pesci. Edizioni Agricole, Bologna, p 24

Smit NJ, Basson L (2002) Gnathia pantherina sp. n. (Crustacea: Isopoda: Gnathiidae), a temporary ectoparasite of some elasmobranch species from southern Africa. Folia Parasitol 49:137-151

Smit NJ, Van As JG, Basson L (1999) A redescription of the adult male and praniza of Gnathia africana Barnard, 1914 (Crustacea: Isopoda: Gnathiidae) from southern Africa. Folia Parasitol 46:229-240

Smit NJ, Van As JG, Basson L (2002) Redescription of the female of Gnathia africana (Crustacea: Isopoda: Gnathiidae) from southern Africa. Folia Parasitol 49:67-72

Stefánsson U (1962) North Icelandic waters. Rit Fiskideildar 3: $1-269$

Svavarsson J (1999) The deep water gnathid Caecognathia bicolour (Hansen, 1916) (Crustacea, Isopoda, Gnathiidae). Rit Fiskideildar 16:171-185

Wagele JW (1988) Aspects of the life-cycle of the Antarctic fish parasite Gnathia calva Vanhoffen (Crustacea: Isopoda). Polar Biol 8:287-291

Submitted: May 14, 2003; Accepted: December 2, 2003

Proofs received from author(s): March 12, 2004 